\title{
SOEP
}

SOEPpapers

on Multidisciplinary Panel Data Research

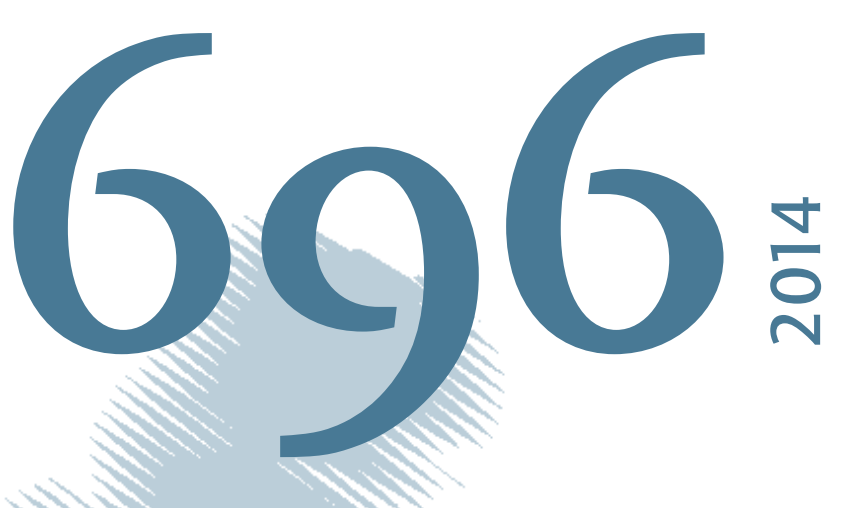

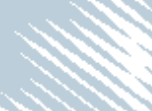

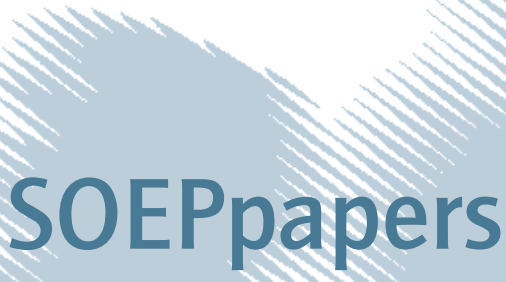

\section{Monitoring Subjective Well-Being: Some New Empirical Evidence for Germany}




\section{SOEPpapers on Multidisciplinary Panel Data Research}

at DIW Berlin

This series presents research findings based either directly on data from the German SocioEconomic Panel Study (SOEP) or using SOEP data as part of an internationally comparable data set (e.g. CNEF, ECHP, LIS, LWS, CHER/PACO). SOEP is a truly multidisciplinary household panel study covering a wide range of social and behavioral sciences: economics, sociology, psychology, survey methodology, econometrics and applied statistics, educational science, political science, public health, behavioral genetics, demography, geography, and sport science.

The decision to publish a submission in SOEPpapers is made by a board of editors chosen by the DIW Berlin to represent the wide range of disciplines covered by SOEP. There is no external referee process and papers are either accepted or rejected without revision. Papers appear in this series as works in progress and may also appear elsewhere. They often represent preliminary studies and are circulated to encourage discussion. Citation of such a paper should account for its provisional character. A revised version may be requested from the author directly.

Any opinions expressed in this series are those of the author(s) and not those of DIW Berlin. Research disseminated by DIW Berlin may include views on public policy issues, but the institute itself takes no institutional policy positions.

The SOEPpapers are available at

http://www.diw.de/soeppapers

\section{Editors:}

Jürgen Schupp (Sociology)

Gert G. Wagner (Social Sciences, Vice Dean DIW Graduate Center)

Conchita D'Ambrosio (Public Economics)

Denis Gerstorf (Psychology, DIW Research Director)

Elke Holst (Gender Studies, DIW Research Director)

Frauke Kreuter (Survey Methodology, DIW Research Professor)

Martin Kroh (Political Science and Survey Methodology)

Frieder R. Lang (Psychology, DIW Research Professor)

Henning Lohmann (Sociology, DIW Research Professor)

Jörg-Peter Schräpler (Survey Methodology, DIW Research Professor)

Thomas Siedler (Empirical Economics)

C. Katharina Spieß (Empirical Economics and Educational Science)

ISSN: 1864-6689 (online)

German Socio-Economic Panel Study (SOEP)

DIW Berlin

Mohrenstrasse 58

10117 Berlin, Germany

Contact: Uta Rahmann | soeppapers@diw.de 
Paper Prepared for the $33^{\text {rd }}$ General Conference of The International Association for Research in Income and Wealth Rotterdam, Netherlands, August 24-30, 2014

\title{
Monitoring Subjective Well-Being: Some New Empirical Evidence for Germany
}

\author{
Erich Oltmanns, Albert Braakmann and Joachim Schmidt \\ Federal Statistical Office / Germany
}

(The views expressed in this paper are those of the authors. They do not necessarily reflect the views of the German Federal Statistical Office.)

For additional information please contact:

Erich Oltmanns

Federal Statistical Office, Germany

Gustav-Stresemann-Ring 11

D-65180 Wiesbaden, Germany

PHONE: +49611 75-2087

FAX: $\quad+4961175-3952$

EMAIL: erich.oltmanns@destatis.de.

The paper is posted on the following website: http://www.iariw.org 


\begin{abstract}
What is subjective well-being influenced by? Since the Report by the Commission on the Measurement of Economic Performance and Social Progress by Stiglitz, Sen and Fitoussi a huge number of studies has raised this question - with partly different findings. In addition, international organizations are increasingly addressing subjective well-being issues. The post-2015 development agenda of the United Nations as well as the inclusive growth strategy of the OECD may be quoted as examples. Facing the current state of national and international discussion, this paper analyses appropriate indicators for the mostly named factors influencing subjective well-being.

The goal of the empirical study for Germany is twofold: First of all, the indicators discussed prominently are analysed with regard to the relevance for explaining the degree of subjective well-being (micro level). Secondly, it is examined, whether the relevance of these indicators changes over time. The empirical results presented in this paper are mainly based on yearly longitudinal data of private households in Germany. Currently, the data set covers about 21,000 individuals living in more than 12,000 private households. The data set provides information on various indicators for subjective well-being mentioned by most of the recent studies, like for instance people's life-circumstances and individual assessments. Concluding remarks concern on one hand the question if data from EU-SILC (because of its Europe-wide coverage) are useful in this context. On the other hand the combination of data at the micro level with indicators at the aggregate level is discussed as well.
\end{abstract}

Keywords: Gross domestic product, Stiglitz-Sen-Fitoussi-Report, quality of life, Socioeconomic panel (SOEP), Germany

JEL classification: C2, D6, I31 


\section{Table of contents}

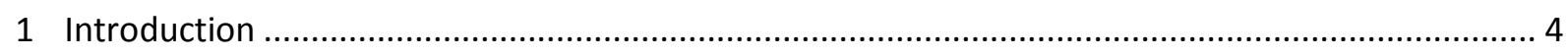

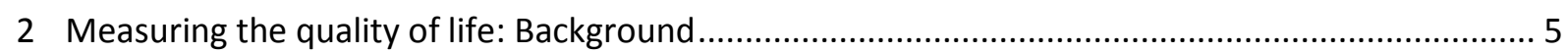

2.1 The Stiglitz-Sen-Fitoussi-Commission and the initiative "GDP and beyond".............................

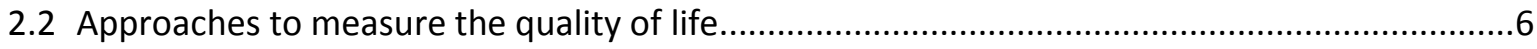

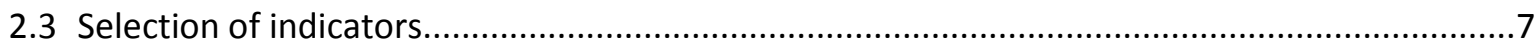

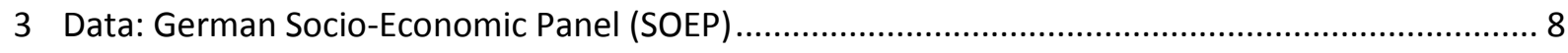

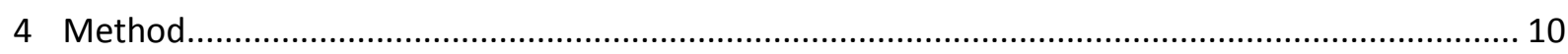

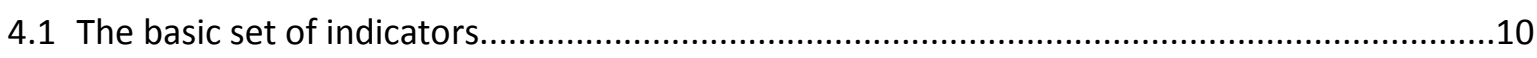

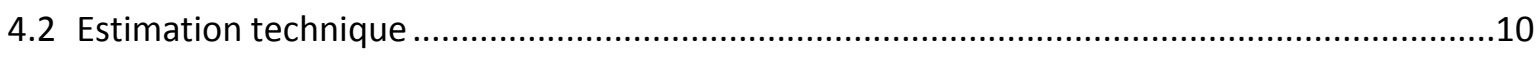

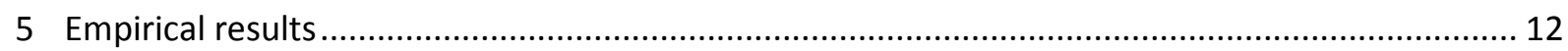

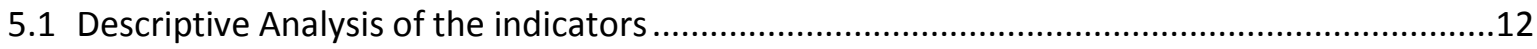

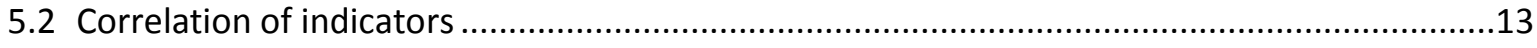

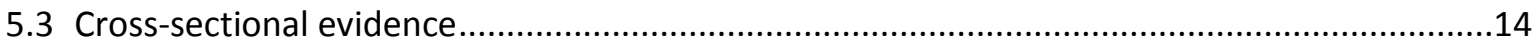

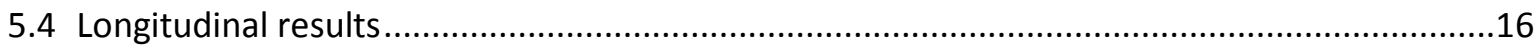

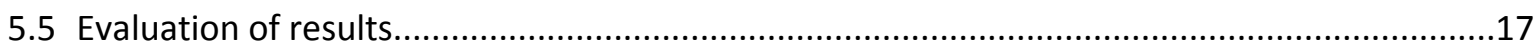

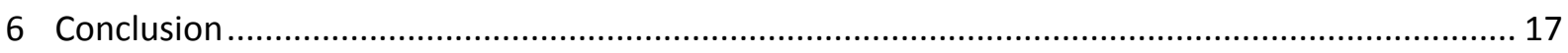

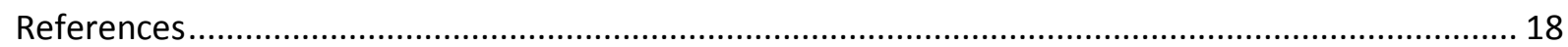




\section{Introduction}

The "Report by the Commission on the Measurement of Economic Performance and Social Progress" by Stiglitz, Sen and Fitoussi has initiated a wide range of papers concerning the measurement of well-being. ${ }^{1}$ The central issue of these contributions is the search for indicators that could supplement the gross domestic product, i. e. to derive additional factors explaining well-being and quality of life.

Progress in economics often can be regarded as circular. Paradigms, ideas and methods arise, vanish and arise again, reflecting the change in the problems of society and economy. It seems that this statement can also be applied to the statistical measurement of wellbeing.

Indeed, criticism on the gross domestic product and discussions about alternative measures of well-being are not new. For instance, in the 1990s the United Nations created the "human development index (HDI)" that combined the GDP with measures of health and educational achievement. In 1992 the UN Summit in Rio de Janeiro brought the notion of Sustainable Development into the policy debate ("Agenda 21"). In the 1970s Nordhaus and Tobin (1973) attempted to develop a measure of economic welfare (MEW), based on GDP, but correcting GDP for its most evident limitations. ${ }^{2}$ And in the year 1972 the "Club of Rome" raised considerable attention with the report "The Limits to Growth".

Already at that time when the concepts of the national accounts were founded, the psychologist and humanistic philosopher Erich Fromm criticised the modern society with its focus set on material wealth: "We consume, as we produce, without any concrete relatedness to the objects with which we deal; we live in a world of things, and our only connection with them is that we know how to manipulate or to consume them. (Fromm, E., 1959, p. 134). And in the 1960 he came to the credo "... that love is the main key to open the doors to the 'growth' of man. Love and union with someone or something outside of oneself, union that allows one to put oneself into relationship with others, to feel one with others, without limiting the sense of integrity and independence." (Fromm, E., 1994)

Expressing it in his words from the mid of the last century Fromm has just dealt with the topic of this paper: it is the search for components or variables that determine the "growth of man", or in modern words: the quality of life of human beings.

Hereunto, the paper is organised as follows: Following this introduction section 2 deals in general with the framework of measuring the quality of life. In section 3 the data to be used for the econometric estimates later in this paper are explained. Section 4 discusses the basic set of variables and the (possible) methods for the estimates. In section 5 the empirical results are presented and the paper ends with some concluding remarks in section 6 .

\footnotetext{
${ }^{1}$ In the following this report is called by its authors "Stiglitz-Sen-Fitoussi-Report".

${ }^{2}$ Commission on the Measurement of Economic Performance and Social Progress (2008), p. 1.
} 


\section{Measuring the quality of life: Background}

\subsection{The Stiglitz-Sen-Fitoussi-Commission and the initiative "GDP and beyond"}

"A discussion on adequate well-being indicators is anything but new. An important academic debate on social and well-being indicators has been going on since the early 70 s. The novelty of the current debate is that the discussion has fully reached and has been forcefully appropriated by the political sphere for the first time." (García Díez, S., 2012, p. 2)

For this new debate two reports are very influential. First of all, it is the "Report of the Commission on the Measurement of Economic Performance and Social Progress" (or "Stiglitz-Sen-Fitoussi-Report"). And on the other side, with the focus set on Europe it is the "Communication from the Commission to the Council and the European Parliament. GDP and beyond. Measuring progress in a changing world" by the European Commission. ${ }^{1}$ These reports discuss the informational value and the shortcomings of the gross domestic product (GDP). They both acknowledge the usefulness of the GDP as an approved economic indicator. But they propose to supplement the GDP by other indicators concerning economic, social and ecological topics.

As one of the reasons for supplementing the GDP by other indicators the Stiglitz-SenFitoussi-Commission considers the concept of the quality of life. To measure the quality of life it is not sufficient to measure the availability of goods and services. It is rather necessary to go beyond the concept of material standard of living and to investigate the determinants of the quality of life. For this purpose the objective features that shape the quality of life have to be identified. According to the Stiglitz-Sen-Fitoussi-Commission seven features indicate the dimensions of the quality of live in addition to the economic conditions:

- Health,

- Education,

- Personal activities,

- Political voice and governance,

- Social connections,

- Environmental conditions

- Personal and economic insecurity.

It is common practice to measure these features in different ways. For instance, health can be measured by the life expectancy at birth, the absence of diseases or healthy live years. Therefore, it is the prior task to identify indicators that predominantly determine these features and the quality of life. And a second and possibly more important question is how to determine factors influencing quality of life. Can experts' proposals be accepted or should they be substantiated by empirical evidence? Do such factors change across countries and/or over time?

\footnotetext{
${ }^{1}$ For an overview see Braakmann, A. (2010).
} 


\subsection{Approaches to measure the quality of life}

Apart from the traditional GDP approach there are four approaches to measure well-being and quality of life respectively. ${ }^{1}$

- Corrected GDP and extended national accounts,

- Composite indexes,

- Subjective approaches and

- Dashboards or sets of indicators.

One of the early attempts to calculate a corrected GDP was done by Nordhaus, W./Tobin, J. (1972). They derive a Measure of Economic Welfare (MEW) by subtracting from total private consumption a number of components that do not contribute positively to welfare (such as commuting or legal services) and by adding monetary estimates of activities that contribute positively to welfare (such as leisure or work at home). Then they convert the MEW in a "sustainable measure of economic welfare" (SMEW) that takes into account changes in total wealth.

The so-called "composite indicators approach" consists in aggregating several elementary indexes to encompass a broad spectrum of dimensions affecting what the indicator wants to measure (human development, well-being, environmental sustainability, etc.). Unlike the "corrected GDP" indicators, this approach does not provide a unified way of measuring heterogeneous dimensions of well-being. The distinctive features of these indicators relate to the domains covered, the normalisation methodology used, and the weights used for aggregation. The most well-known composite indicator is the Human Development Index (HDI) proposed by the United Nation Development Programme (UNDP) in 1990. The HDI consists of a weighted average of GDP, life expectancy and education measures (adult literacy rate and school entry rates).

A third group of approaches consists of measures of subjective well-being. Subjective approaches are based on the idea that individuals themselves are the best judges of their quality of life. So, it is the best way to ask them directly about their well-being, which in practice can be done by using different methods. Meanwhile, there are several surveys that include questions about well-being. For instance, EU-SILC, the European "Statistics on income, social inclusion and living conditions", which started in 2003 and is conducted in the member states of the European Union, in Switzerland, Norway, Island, Turkey, Croatia, Serbia and Macedonia, includes questions about poverty, social exclusion, education and health. ${ }^{2}$

The fourth approach to measure quality of life is to apply dashboards or sets of indicators. Sets of indicators have a long tradition. In the 1970s the OECD initiated an ambitious statistical program on social indicators. In the midst of the 1980s their influence decreased, but they have come back to life in the 1990s, represented by the "Sustainable Development In-

\footnotetext{
${ }^{1}$ For a synopsis of these approaches see Commission on the Measurement of Economic Performance and Social Progress (2008). The survey is also the basis for this section.

${ }^{2}$ See Eurostat (2010).
} 
dicators of the United Nations. And in 2011 the OECD launched its "Better Life Index" that covers 11 dimensions of the OECD well-being framework. ${ }^{1}$

Sets of indicators "typically refer to descriptive measures of average conditions of people living in different countries, with indicators covering a large number of domains. Recent initiatives on indicator sets share some specific characteristics that differentiate them from earlier developments. First, these initiatives have often a strong environmental focus, within the broader agenda of sustainable development. Second, these developments are often more participatory, developed at the local level by groups that use indicators as part of a strategy aimed to mobilize action on specific issues. Third, these indicator sets are often specifically tailored to the needs of policy makers." (Commission on the Measurement of Economic Performance and social Progress ..., 2008, p. 8)

\subsection{Selection of indicators}

As there are several very different approaches to measure the quality of life this leads to the question which approach should be preferred. It is not straightforward to find an answer. Every approach has it pros and cons. But an answer can be found on a very pragmatic level: Currently, the political discussion is focussing on sets of indicators. Not only the Stiglitz-SenFitoussi-Report, but also the Commission of the European Communities (2009) or the German Council of Economic Experts and Conseil d'Analyse Economique (2010) discuss or propose respectively dashboards or set of indicators. ${ }^{2}$ And in 2013 the "Study Commission on Growth, Well-being and Quality of Life" of the German Bundestag proposed the so-called set

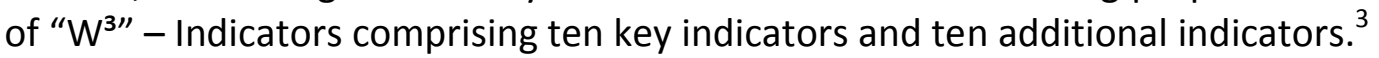

To contribute to this discussion it would be very useful to investigate the question which indicators predominantly determine the quality of life. One approach for Germany was proposed by Kassenboehmer and Schmidt (2011): They analyse data at the macro level from the German Federal Statistical Office combined with micro level data from the German SOEP (1991-2008) on the personal work situation and subjective feelings concerning several aspects of life. Employing the indicators suggested by the Stiglitz-Sen-Fitoussi-Report, they come to the result that much of the variation in many well-being measures can be captured well by the hard economic indicators as used in the literature, especially by GDP and the unemployment rate. But they also see that these correlations are far from perfect, thus giving considerable hope that there is room for a broader statistical reporting.

Following and discussing the approach of Kassenboehmer and Schmidt (2011) in the next section it is tried to discuss indicators that predominantly determine the quality of life. As this is also done in Oltmanns, Braakmann and Schmidt (2012), the focus is set on analysing the differences that result from the enlarged database.

\footnotetext{
${ }^{1}$ See OECD (2013), p. 20.

${ }^{2}$ The Conseil d'Analyse Economique ist the French counterpart to the German Council of Economic Experts.

${ }^{3}$ See Study Commission on Growth, Well-being and Quality of Life (2013).
} 


\section{Data: German Socio-Economic Panel (SOEP)}

The first step to search for indicators that determine the satisfaction with life is to find an appropriate data base. For instance, results from EU-SILC could be used. The advantage of this survey is that it covers many European countries. ${ }^{1}$ On the other side, it is the aim of this study to begin with the results of Kassenboehmer and Schmidt (2011). As they use data from the German Socio-Economic Pane (SOEP), it is self-evident also to use these data.

Table 1: Subsamples of the SOEP $2011^{2}$

\begin{tabular}{|c|c|c|c|c|}
\hline Sample & $\begin{array}{l}\text { Start- } \\
\text { Year }\end{array}$ & $\begin{array}{l}\text { House- } \\
\text { holds }\end{array}$ & Persons & Description \\
\hline $\begin{array}{l}\text { A West-German } \\
\text { residents }\end{array}$ & 1984 & \multirow{2}{*}{2,539} & \multirow{2}{*}{4,451} & $\begin{array}{l}\text { Head is either German or other nationality } \\
\text { than those in Sample B }\end{array}$ \\
\hline B Foreigners & 1984 & & & $\begin{array}{l}\text { Head is either Turkish, Italian, Spanish, } \\
\text { Greek or from the former Yugoslavia }\end{array}$ \\
\hline C East-Germans & 1990 & 1,355 & 2,392 & $\begin{array}{l}\text { Head was a citizen of the GDR (expansion of } \\
\text { survey territory) }\end{array}$ \\
\hline \multirow[t]{2}{*}{ D Immigrants } & 1994 / & \multirow[t]{2}{*}{266} & \multirow[t]{2}{*}{461} & \multirow{2}{*}{$\begin{array}{l}\text { At least one household member has moved } \\
\text { to Germany after } 1989 \text { (expansion of survey } \\
\text { population) }\end{array}$} \\
\hline & 1995 & & & \\
\hline E Refreshment & 1998 & 545 & 961 & $\begin{array}{l}\text { Random sample covering all existing sub- } \\
\text { samples (total population) }\end{array}$ \\
\hline F Innovation & 2000 & 2,885 & 4,984 & $\begin{array}{l}\text { Random sample covering all existing sub- } \\
\text { samples (total population) }\end{array}$ \\
\hline G High Income & 2002 & 706 & 1,358 & $\begin{array}{l}\text { Monthly net household income is more } \\
\text { than } 4.500 \text { Euro ( } 7.500 \mathrm{DM})\end{array}$ \\
\hline H Refreshment & 2006 & 858 & 1,478 & $\begin{array}{l}\text { Random sample covering all existing sub- } \\
\text { samples (total population) }\end{array}$ \\
\hline I Incentive & 2009 & - & - & $\begin{array}{l}\text { Random sample covering all existing sub- } \\
\text { samples (total population); since } 2011 \text { part } \\
\text { of the SOEP Innovation Sample (SOEP-IS) }\end{array}$ \\
\hline J Refreshment & 2011 & 3136 & 5161 & $\begin{array}{l}\text { Random sample covering all existing sub- } \\
\text { samples (total population) }{ }^{4}\end{array}$ \\
\hline
\end{tabular}

The SOEP is a longitudinal panel dataset of the population in Germany that started in $1984 .^{5}$ It is a household based study which re-interviews adult household members annually. Altogether, the panel consists of nine subsamples: The survey began in 1984 with two subsam-

\footnotetext{
${ }^{1}$ Frick, J and K. Krell (2011) compare EU-SILC and the SOEP concerning income analysis for Germany.

${ }^{2}$ The figures concern to the number of successful interviews in 2011. See Kroh, M. (2014), p. $6-12$.

${ }^{3}$ See Frick, J. and I. Sieber (2012), p.3

${ }^{4}$ See http://www.diw.de/en/diw 01.c.390440.en/soep is.html.

${ }^{5}$ For a description of the SOEP see Haisken-DeNew, J. P. and J. Frick (2005), Wagner, Gert G., Joachim R. Frick and Jürgen Schupp (2007) and http://en.wikipedia.org/wiki/Socio-Economic_Panel.
} 
ples: West German residents (subsample " $A$ ") and the subsample "B" of households with a head from a foreign country. After the German reunification they were supplemented by the subsample " $C$ " with East German residents. In the following years these were supplemented by the subsamples " $\mathrm{D}$ " to " $\mathrm{H}$ " to consider the role of immigrants in Germany or to refresh the samples. The last subsamples "J" and " $\mathrm{K}$ " were introduced in 2011 and 2012. ${ }^{1}$ The subsamples are described in Table 1. In 2011, there were about 12,000 households, and more than 21,000 adult persons inquired.

Table 2: Variables of the estimated models ${ }^{2}$

\begin{tabular}{l|l|l}
\hline Variable & Description & Unit/Code/Remarks \\
\hline SATLIFE & $\begin{array}{l}\text { Satisfaction with life at today } \\
\text { SATHEALTaction with health } \\
\text { SATWORK }\end{array}$ & 0-low to 10-high \\
\hline WORRYECON & Worried about economic development & \\
WORRYECSIT & Worried about finances & 1 Very concerned \\
WORRYENV & Worried about environment & 2 Somewhat concerned \\
WORRYIOB & Worried about job security & 3 Not concerned \\
WORRYPEACE & Worried about peacekeeping & \\
\hline LABNET & Current net labour income & \\
OVERTIME & Hours of overtime last month & Euro; generated variable \\
UNEMPLYD & Registered unemployed & Hours \\
EDUCATION & Amount of education or training in years & 1 yes ; 2 no \\
\hline YEARBIRTH & Year of birth & Year \\
MARITALSTATUS & Marital status in survey year & Nominal \\
NATION & Nationality & Nominal ; generated var. \\
\hline
\end{tabular}

The topics surveyed by the SOEP include questions concerning ${ }^{3}$

- Demography and housing,

- Personality traits und basic attitudes,

- Social capital and leisure time,

- Education,

- Labour market and employment

- Income, wealth and social security

- Health,

- Subjective indicators on social inclusion/exclusion (worries, satisfaction with life).

\footnotetext{
${ }^{1}$ Subsample $\mathrm{K}$ is neglected here, because only data until 2011 are used for the estimations.

${ }^{2}$ See Goebel, J. (2014a) and Goebel, J. (2014b).

${ }^{3}$ See Gert G.Wagner, Jan Goebel, Peter Krause, Rainer Pischner and Ingo Sieber (2008), p. 305.
} 
SOEP data are integrated into the Cross National Equivalent File (CNEF) which contains panel data from Australia, Canada, Germany, Great Britain and the United States. The data distribution of the SOEP for researchers outside of Germany is supplied with the CNEF by a group at Cornell University.

\section{Method}

\subsection{The basic set of indicators}

As it is an intention of this paper to discuss the results of Kassenboehmer and Schmidt (2011) the selection of indicators used for the estimated models is widely determined by their approach. All in all they have twelve variables for their investigation on the micro-level. These are shown in Table 2 on page 9. ${ }^{1}$

The variable SATLIFE represents general satisfaction with life. It is measured on a scale from 0 ("low") to 10 ("high). On the same scale the variables SATHEALTH ("Satisfaction with health") and SATWORK ("Satisfaction with work") are measured. These variables represent so-called areas of satisfaction.

Five indicators describe special worries, ranging from individual worry about own finances and job security to rather general worries about environment and peace. These indicators are measured on a scale from 1 ("very concerned") to 3 ("not concerned").

The indicator LABNET represents the current net labour income. It is a so-called generated variable. ${ }^{2}$ This variable is measured in Euro. The further variables used by Kassenboehmer and Schmidt (2011) are OVERTIME, UNEMPLYD and EDUCATION.

The variable YEARBIRTH is no part of the investigation of Kassenboehmer and Schmidt (2011). In this study the meaning of this variable is twofold. First of all, it is used to include only adults into the dataset. Secondly, YEARBIRTH serves as a control variable for some models to be estimated later. The other control variables are MARITALSTATUS and NATION. MARITALSTATUS is a variable empirically measured and NATION is a generated variable.

\subsection{Estimation technique}

There are several methodological approaches to investigate the question what kind of indicators determines the quality of live.

Kassenboehmer and Schmidt (2011) carry out their analysis using principal component factor analysis. It is the aim of the factor analysis to reduce the number of variables to a set of hypothetic variables, the so-called factors. Especially, in their paper the observed variables income, unemployment etc. is supposed to be presented by a smaller number of variables.

\footnotetext{
${ }^{1}$ Kassenboehmer and Schmidt (2011) have also an approach based on macro-data with partly different variables. For instance, they use GDP instead of (monthly) labour income, unemployment rate instead of the dummy for unemployment. But this approach on the macro-level is not investigated here.

${ }^{2}$ Generated variables are no part of the SOEP-survey. They supplement the survey data to facilitate the analysis.
} 
Then, applying statistical measures it would be possible to select observed variables that are appropriate to represent the dimensions of wealth.

Factor analysis serves as a tool to reduce dimensions (of the data). It is a linear model between factors and variables. Because of the high number of unknown parameters the general model of factor analysis is not without ambiguity and problems of identification concerning the problem of communalities, the problem of rotation or the number of variables to be extracted. These problems are an integral part of the factor analysis and they only can be solved by introducing very restrictive assumptions. For this reason, the factors found by the factor analysis should not be interpreted as determining variables, but rather as variables that condense the information contained in the data. To find causalities between variables it would be useful to apply other methods.

First of all, it is possible to use the classical multiple linear regression model. The advantage of the multiple regression model can be described as follows: "The linear regression model is the single most useful tool in the econometrician kit. Although to an increasing degree in contemporary research it is often only the departure point for the full analysis, it remains the device used to begin all empirical research. And, it is the lens through which relationships among variables are usually viewed." (Greene, W., 2012, p. 52) The linear regression model can be estimated with the pooled data from 1991 to 2009 or with data for single years.

One of the assumptions of the linear regression model are normal distributed residuals and homoscedasticity of the residuals. This implies that the variables of the model, especially the dependent variable, are also normally distributed and of a quantitative nature. But almost all variables described above do not hold this assumption. They are the result of an ordered choice measured on different scales. "The numerical values are only a ranking, not a quantitative measure. Thus a " 1 " is greater than a " 0 " in a qualitative sense, but not by one unit, and the difference between a " 2 " and a " 1 " is not the same as that between a " 1 " and a "0"." (Greene, W., 2012, p. 722). To consider the shortcomings of the linear regression model it would be useful to apply logit or probit models. On the other hand, SATLIFE, the variable to be predicted, is measured on a scale from " 0 " to " 10 ", which implies a binomial distribution for the sample. The discrete binomial distribution converges to the normal distribution for big samples. So, the assumptions of the linear regression model may be fulfilled asymptotically and the linear regression model could lead to useful results. Hajek, A. (2011) argues that the question if the satisfaction with life should be measured on an ordered scale or on an continuous scale has no clear answer. Psychologist and sociologist would treat satisfaction with life as continuous using OLS-regressions (Kahneman, Diener and Schwarz, 1999) whereas economists would apply ordered response models based on the assumption of an ordinal variable (for instance, Ferrer-i-Carbonell and Fritjers, 2004). Furthermore, Ferrer-iCarbonell and Fritjers (2004) and Blanchflower (2009) would argue, that it does not matter if satisfaction with life is treated as ordinal or continuous.

In this paper the analysis predominantly uses OLS regressions. First of all, a detailed analysis is done for 2011. Then, the results of 2011 are compared with the results for the years 1991 and 2001. Hereafter, the regression is carried out with the pooled data from 1991 to 2011. 
Table 3: Descriptive statistics. Data for 2011

\begin{tabular}{|c|c|c|c|c|c|}
\hline Variable & $\mathrm{N}$ & $\begin{array}{c}\text { Arithmetic } \\
\text { mean }\end{array}$ & $\begin{array}{l}\text { Standard } \\
\text { deviation }\end{array}$ & $\begin{array}{l}\text { Mini- } \\
\text { mum }\end{array}$ & $\begin{array}{l}\text { Maxi- } \\
\text { mum }\end{array}$ \\
\hline SATLIFE & 18182 & 6.91 & 1.77 & 0.00 & 10.00 \\
\hline SATHEALTH & 18206 & 6.51 & 2.20 & 0.00 & 10.00 \\
\hline SATWORK & 10919 & 6.83 & 2.18 & 0.00 & 10.00 \\
\hline WORRYECON & 18170 & 1.62 & 0.59 & 1.00 & 3.00 \\
\hline WORRYECSIT & 18158 & 2.02 & 0.69 & 1.00 & 3.00 \\
\hline WORRYENV & 18160 & 1.88 & 0.62 & 1.00 & 3.00 \\
\hline WORRYJOB & 10450 & 2.31 & 0.71 & 1.00 & 3.00 \\
\hline WORRYPEACE & 18170 & 1.86 & 0.67 & 1.00 & 3.00 \\
\hline LABNET & 18237 & 917.58 & 1262.84 & 0.00 & 20000.00 \\
\hline OVERTIME & 4301 & 18.97 & 17.32 & 1.00 & 99.00 \\
\hline UNEMPLYD & 18237 & 1.94 & 0.24 & -1.00 & 2.00 \\
\hline EDUCATION & 17046 & 12.26 & 2.71 & 7.00 & 18 \\
\hline \multirow[t]{2}{*}{ YEARBIRTH (Age) } & 18237 & 51,89 & 17.65 & 18 & 99 \\
\hline & \multicolumn{3}{|c|}{ Value } & $\mathrm{N}$ & $\%$ \\
\hline \multirow[t]{6}{*}{ MARITALSTATUS } & & 12413 & 58.92 \\
\hline & \multicolumn{3}{|c|}{ Married, live separated } & 380 & 1.80 \\
\hline & \multicolumn{3}{|l|}{ Single } & 4933 & 23.41 \\
\hline & \multicolumn{3}{|c|}{ Divorced } & 1783 & 8.46 \\
\hline & \multicolumn{3}{|c|}{ Widowed } & 1512 & 7.18 \\
\hline & \multicolumn{3}{|l|}{ Total } & 21021 & 100.00 \\
\hline \multirow[t]{9}{*}{ NATION } & \multicolumn{3}{|c|}{ Germany } & 20262 & 94.97 \\
\hline & \multicolumn{3}{|c|}{ Turkey } & 256 & 1.20 \\
\hline & \multicolumn{3}{|l|}{ Italy } & 165 & 0.77 \\
\hline & \multicolumn{3}{|l|}{ Greece } & 79 & 0.37 \\
\hline & \multicolumn{3}{|l|}{ Croatia } & 70 & 0.33 \\
\hline & \multicolumn{3}{|l|}{ Austria } & 40 & 0.19 \\
\hline & \multicolumn{3}{|l|}{ Spain } & 34 & 0.16 \\
\hline & \multicolumn{3}{|l|}{ Others } & 430 & 2.02 \\
\hline & \multicolumn{3}{|l|}{ Total } & 21336 & 100.00 \\
\hline
\end{tabular}

\section{Empirical results}

\subsection{Descriptive Analysis of the indicators}

Table 3 shows some descriptive information about the indicators used for the estimates of the models for 2011. MARITALSTATUS and NATION are nominal variables. Therefore, only absolute and relative frequencies are calculated. Both variables are shown here divided by subcategories. All subcategories for MARITALSTATUS are listed, but for NATION only the most frequently categories. For the purpose of regression estimates both variables are transformed to dummy variables with "Married, live together" $=1 /$ "Otherwise" $=0$ and "Germa$n y^{\prime \prime}=1 /$ "Otherwise" $=0$. The results differ slightly from those of Oltmanns, Braakmann and 
Schmidt (2012). But the differences are fare away from yielding substantial opportunities for interpretation.

Table 4: Correlation coefficients of the variables (Bravais-Pearson) 2011

\begin{tabular}{|c|c|c|c|c|c|c|c|c|c|c|c|c|c|}
\hline & 岂 & 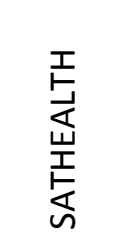 & 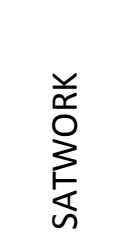 & 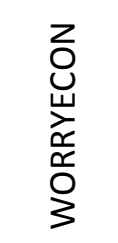 & 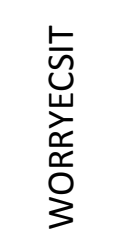 & 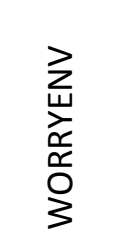 & 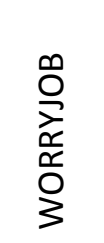 & 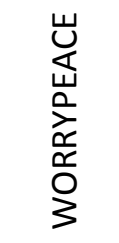 & 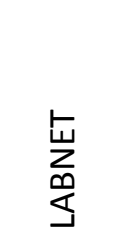 & 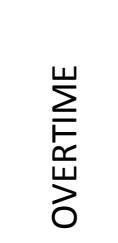 & 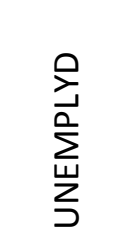 & 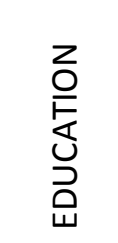 & 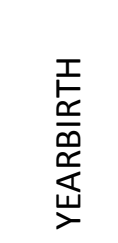 \\
\hline SATLIFE & 1.000 & 0.504 & 0.455 & 0.131 & 0.362 & 0.020 & 0.043 & 0.269 & 0.017 & -0.008 & 0.176 & 0.028 & 0.053 \\
\hline SATHEALTH & 0.504 & 1.000 & 0.396 & 0.104 & 0.161 & 0.070 & 0.085 & 0.140 & 0.017 & -0.002 & 0.056 & 0.028 & 0.325 \\
\hline SATWORK & 0.455 & 0.396 & 1.000 & 0.105 & 0.289 & 0.018 & 0.036 & 0.294 & 0.018 & -0.027 & 0.214 & 0.028 & 0.068 \\
\hline WORRYECON & 0.131 & 0.104 & 0.105 & 1.000 & 0.347 & 0.260 & 0.267 & 0.224 & 0.001 & -0.012 & 0.026 & 0.007 & 0.094 \\
\hline WORRYECSIT & 0.362 & 0.161 & 0.289 & 0.347 & 1.000 & 0.095 & 0.188 & 0.512 & 0.033 & 0.018 & 0.195 & 0.049 & -0.155 \\
\hline WORRYENV & 0.020 & 0.070 & 0.018 & 0.260 & 0.095 & 1.000 & 0.473 & 0.047 & -0.005 & 0.025 & -0.003 & -0.005 & 0.078 \\
\hline WORRYJOB & 0.043 & 0.085 & 0.036 & 0.267 & 0.188 & 0.473 & 1.000 & 0.128 & 0.017 & 0.049 & 0.022 & 0.008 & 0.091 \\
\hline WORRYPEACE & 0.269 & 0.140 & 0.294 & 0.224 & 0.512 & 0.047 & 0.128 & 1.000 & 0.027 & 0.005 & 0.099 & 0.041 & -0.098 \\
\hline LABNET & 0.017 & 0.017 & 0.018 & 0.001 & 0.033 & -0.005 & 0.017 & 0.027 & 1.000 & 0.011 & 0.022 & 0.357 & 0.002 \\
\hline OVERTIME & -0.008 & -0.002 & -0.027 & -0.012 & 0.018 & 0.025 & 0.049 & 0.005 & 0.011 & 1.000 & 0.034 & 0.015 & -0.059 \\
\hline UNEMPLYD & 0.176 & 0.056 & 0.214 & 0.026 & 0.195 & -0.003 & 0.022 & 0.099 & 0.022 & 0.034 & 1.000 & 0.009 & -0.110 \\
\hline EDUCATION & 0.028 & 0.028 & 0.028 & 0.007 & 0.049 & -0.005 & 0.008 & 0.041 & 0.357 & 0.015 & 0.009 & 1.000 & -0.013 \\
\hline YEARBIRTH & 0.053 & 0.325 & 0.068 & 0.094 & -0.155 & 0.078 & 0.091 & -0.098 & 0.002 & -0.059 & -0.110 & -0.013 & 1.000 \\
\hline
\end{tabular}

\subsection{Correlation of indicators}

In Table 4 the correlation between the variables for 2011 is shown. All variables are treated as numeric. Therefore the correlation coefficient of Bravais-Pearson was pairwise calculated. The calculation of the correlation coefficient of Spearman that would be more appropriate for ordered data led to similar results. Compared to Oltmanns, Braakmann and Schmidt (2012) the interpretation of results has not changed.

Altogether, the correlations between the variables are not very strong. None of the values exceeds 0.6 and only a few are higher than 0.4 . For the purpose of regression analysis this result has its advantage. Poor correlation between the variables can mean that the variables are appropriate to explain the behaviour (or deviation) of the dependent variable.

Only some of the variables show a correlation that should be expected. There is a pairwise correlation between SATLIFE, SATHEALTH, SATWORK and WORRYECSIT and also a correlation between EDUCATION and LABNET. On the other side, the lack of correlation between 
some variables is fare from intuition. For instance, it should be clear that there is a strong relationship between the year of birth and income or between income and the hours of overtime. But both parameters are near zero.

\subsection{Cross-sectional evidence}

In general, the investigation of cross-sectional evidence starts with all variables used by Kassenboehmer and Schmidt (2011). But including the variable UNEMPLYD makes it necessary to group the regression equations. If the status of UNEMPLYD is "YES", it is not very useful to include the variables LABNET, WORRYJOB and OVERTIME. Therefore, the estimates are grouped by UNEMPLYD and the variables mentioned are skipped for UNEMPLYD = "Yes".

The results of the grouped regressions are shown in Table a and b. Model 1 includes all variables of Kassenboehmer and Schmidt (2011) for the employed and the reduced set for the unemployed respectively. First of all, the groups have a lot in common. As shown by the Fvalue the models for both groups are significant. Satisfaction with health and work and the (absence of) worry about the own economic situation have a significant influence on the satisfaction with life, as well as the variable WORRYJOB for the group of the employed. For both groups the other variables have no significant influence on the satisfaction of life.

Table 5a: Estimation results for grouped regression 2011

\begin{tabular}{|c|c|c|c|c|c|c|c|c|}
\hline \multirow[b]{2}{*}{ Variable } & \multicolumn{2}{|c|}{ Model 1: Full model } & \multicolumn{2}{|c|}{$\begin{array}{l}\text { Model 2: Fore- } \\
\text { ward selection }\end{array}$} & \multicolumn{2}{|c|}{$\begin{array}{l}\text { Model 3: Back- } \\
\text { ward selection }\end{array}$} & \multicolumn{2}{|c|}{$\begin{array}{l}\text { Model 4: Free- } \\
\text { hand-selection }\end{array}$} \\
\hline & Estimate & P-value & Estimate & P-value & Estimate & P-value & Estimate & P-value \\
\hline & \multicolumn{8}{|c|}{ Regression on SATLIFE ; UNEMPLYD = No } \\
\hline Intercept & 2.32452 & $<.0001$ & 2.64654 & $<.0001$ & 2.72356 & $<.0001$ & 2.58885 & $<.0001$ \\
\hline SATHEALTH & 0.27829 & $<.0001$ & 0.28375 & $<.0001$ & 0.28913 & $<.0001$ & 0.28766 & $<.0001$ \\
\hline SATWORK & 0.21469 & $<.0001$ & 0.20027 & $<.0001$ & 0.19166 & $<.0001$ & 0.19241 & $<.0001$ \\
\hline WORRYECON & -0.02423 & 0.5282 & & & & & & \\
\hline WORRYECSIT & 0.47314 & $<.0001$ & 0.49289 & $<.0001$ & 0.56989 & $<.0001$ & 0.56621 & $<.0001$ \\
\hline WORRYENV & -0.03647 & 0.3356 & -0.09192 & $<.0001$ & -0.07716 & 0.0002 & & \\
\hline WORRYJOB & 0.14098 & $<.0001$ & 0.10725 & $<.0001$ & & & & \\
\hline WORRYPEACE & -0.01735 & 0.6266 & & & & & & \\
\hline LABNET & -0.00001 & 0.7624 & & & & & & \\
\hline OVERTIME & 0.00018 & 0.8746 & & & & & & \\
\hline EDUCATION & 0.01362 & 0.0853 & -0.00065 & 0.8965 & & & & \\
\hline F-Value (model) & 231.94 & $<.0001$ & 879.58 & $<.0001$ & 1490.73 & $<.0001$ & 1985.91 & $<.0001$ \\
\hline Observations & \multicolumn{2}{|c|}{3918} & \multicolumn{2}{|c|}{9128} & \multicolumn{2}{|c|}{10503} & \multicolumn{2}{|c|}{10513} \\
\hline
\end{tabular}

All in all, the results for Model 1 are unambiguous. But they differ substantially from the results for the year 2008 presented in Oltmanns, Braakmann and Schmidt (2012). For 2008 also the variables WORRYENV, WORRYPEACE and LABNET had a significant influence on satisfaction with life for the employed. And WORRYENV was significant for the group of the unemployed. To find an explanation for this change of parameters for these models is not straightforward. One could expect that changes in the explaining model occur stepwise. But 
on the other hand, 2008 the bankruptcy of the Lehman Brothers took place and the great depression began. ${ }^{1}$ And it is quite understandable that in the following years, including 2011, the focus is set on worries about the own economic situation.

Table 5b: Estimation results for grouped regression 2011

\begin{tabular}{|c|c|c|c|c|c|c|c|c|}
\hline \multirow[b]{2}{*}{ Variable } & \multicolumn{2}{|c|}{ Model 1: Full model } & \multicolumn{2}{|c|}{$\begin{array}{l}\text { Model 2: Forward } \\
\text { selection }\end{array}$} & \multicolumn{2}{|c|}{$\begin{array}{l}\text { Model 3: Back- } \\
\text { ward selection }\end{array}$} & \multicolumn{2}{|c|}{$\begin{array}{l}\text { Model 4: Free- } \\
\text { hand-selection }\end{array}$} \\
\hline & Estimate & P-value & Estimate & P-value & Estimate & P-value & Estimate & P-value \\
\hline & \multicolumn{8}{|c|}{ Regression on SATLIFE ; UNEMPLYD = Yes } \\
\hline Intercept & 2.51566 & 0.0001 & 2.76082 & 0.0001 & 2.23116 & $<.0001$ & 2.23116 & $<.0001$ \\
\hline SATHEALTH & 0.25401 & $<.0001$ & 0.23323 & 0.0004 & 0.24903 & $<.0001$ & 0.24903 & $<.0001$ \\
\hline SATWORK & 0.15656 & $<.0001$ & 0.16061 & 0.0015 & 0.15793 & $<.0001$ & 0.15793 & $<.0001$ \\
\hline WORRYECON & 0.15183 & 0.4371 & 0.19420 & 0.4803 & & & & \\
\hline WORRYECSIT & 0.79793 & $<.0001$ & 1.08200 & $<.0001$ & 0.83755 & $<.0001$ & 0.83755 & $<.0001$ \\
\hline WORRYENV & -0.19860 & 0.3371 & -0.20498 & 0.4698 & & & & \\
\hline WORRYPEACE & -0.14711 & 0.4221 & -0.18276 & 0.3459 & & & & \\
\hline EDUCATION & 0.01019 & 0.7729 & -0.24350 & 0.3272 & & & & \\
\hline F-Value (model) & 16.98 & $<.0001$ & 9.24 & $<.0001$ & 43.32 & $<.0001$ & 43.32 & $<.0001$ \\
\hline Observations & 319 & & $10 \varepsilon$ & & 34 & & 34 & \\
\hline
\end{tabular}

Model 2 and Model 3 are the result of automated model selection: forward selection and backward selection based on all variables of Model $1 .{ }^{2}$ The model specifications are similar to the specification of Model 1, what means that SATHEALTH, SATWORK and WORRYECSIT have a significant influence. For the group of the unemployed the results of forward selection and backward selection are identical with Model 1. For the group of the employed the variable WORRYENV is included but has the wrong sign for both models ( 2 and 3 ). Additionally, Model 2 and Model 3 for the group of the employed differ by the variable WORRYJOB. This may be a result of the different techniques of model selection that are both based on the F-value of the model. Model 4 is the result of freehand selection. For both groups the same set of indicators was selected: SATHEALTH, SATWORK and WORRYECSIT.

Altogether, the results of the four models lead to a unique selection of variables. In all cases satisfaction with health, satisfaction with work and worries about the own economic situation seem to be important for satisfaction with life. As this result differs from the outcome of Oltmanns, Braakmann and Schmidt (2012), in the next chapter the reasons for these differences have to be discussed.

\footnotetext{
${ }^{1}$ Strictly spoken the great depression was sparked in 2007 by the U.S. Subprime mortgage crisis. But the exact point of time is not important here.

${ }^{2}$ The criterion to select or drop variables was the $p$-value of the F-statistics of the model. As a third automated method Stepwise selection was applied. Stepwise selection is not reported in Table, because it led to the same results as the backward selection.For a discussion of the problem of model selection see for instance Greene, W. (2012), p. $178-181$.
} 


\subsection{Longitudinal results}

To get longitudinal results, the estimates were repeated with data for 1992, 2001 and for the pooled data from 1992 to $2011 .^{1}$

First of all, the approach of Oltmanns, Braakmann and Schmidt (2012) was kept. That means, that several control variables are added now: Age, marital status and nationality. Even, if these variables may have an influence on the quality of life they were not included before, because it was the intention to investigate the impact of the variables of Kassenboehmer and Schmidt (2011) exclusively. Now, in the following step it is not only the intention to investigate the longitudinal aspect of the estimates but also to try to improve the model specifications.

With these modifications in mind the results confirm the estimates of the previous chapter. For 1992, 2001 and 2011 as well as for the pooled data for 1992 to 2011 SATHEALTH, SATWORK, WORRYECSIT and WORRYJOB have a significant influence on the satisfaction with life. The influence of some other variables is ambiguous. For instance, WORRYECON is significant for 2001 and for the pooled data set, LABNET for 1992 and the pooled data.

\begin{tabular}{|c|c|c|c|c|c|c|c|c|}
\hline \multicolumn{9}{|c|}{ Table 6: Estimation results for 1992, 2001, 2011 and 1992 to 2011} \\
\hline & \multicolumn{2}{|c|}{ Model 5: 1992} & \multicolumn{2}{|c|}{ Model 6: 2001} & \multicolumn{2}{|c|}{ Model 7: 2011} & \multicolumn{2}{|c|}{$\begin{array}{c}\text { Model 8: } 1992- \\
2011 \text { (pooled data) }\end{array}$} \\
\hline & \multicolumn{8}{|c|}{ Regression on SATLIFE ; UNEMPLYD = No } \\
\hline Variable & Estimate & P-value & Estimate & P-value & Estimate & P-value & Estimate & P-value \\
\hline Intercept & 2.39347 & $<.0001$ & 2.68566 & $<.0001$ & 2.52446 & $<.0001$ & 2.52046 & $<.0001$ \\
\hline SATHEALTH & 0.23888 & $<.0001$ & 0.25313 & $<.0001$ & 0.28522 & $<.0001$ & 0.26597 & $<.0001$ \\
\hline SATWORK & 0.24454 & $<.0001$ & 0.20513 & $<.0001$ & 0.19919 & $<.0001$ & 0.21073 & $<.0001$ \\
\hline WORRYECON & -0.00736 & 0.7949 & 0.07349 & 0.0010 & 0.02096 & 0.4042 & 0.03864 & $<.0001$ \\
\hline WORRYECSIT & 0.48132 & $<.0001$ & 0.50505 & $<.0001$ & 0.50480 & $<.0001$ & 0.50575 & $<.0001$ \\
\hline WORRYENV & -0.02287 & 0.4530 & -0.04751 & 0.0378 & -0.04670 & 0.0569 & -0.00814 & 0.0004 \\
\hline WORRYJOB & 0.16800 & $<.0001$ & 0.06485 & 0.0012 & 0.10847 & $<.0001$ & 0.09409 & $<.0001$ \\
\hline WORRYPEACE & -0.05595 & 0.0328 & -0.06743 & 0.0012 & -0.07543 & 0.0011 & -0.08158 & $<.0001$ \\
\hline LABNET & 0.00011 & $<.0001$ & 0.00002 & 0.1166 & $>-0.00001$ & 0.8563 & 0.00002 & $<.0001$ \\
\hline MARITALSTATUS & 0.06943 & 0.0532 & 0.20830 & $<.0001$ & 0.24813 & $<.0001$ & 0.19216 & $<.0001$ \\
\hline NATION & -0.30230 & $<.0001$ & -0.07000 & 0.0899 & -0.04925 & 0.3855 & -0.09452 & $<.0001$ \\
\hline F-Value (model) & 444.11 & $<.0001$ & 643.13 & $<.0001$ & 580.02 & $<.0001$ & 10715.8 & $<.0001$ \\
\hline Observations & \multicolumn{2}{|c|}{7606} & \multicolumn{2}{|c|}{11984} & \multicolumn{2}{|c|}{9958} & \multicolumn{2}{|c|}{189551} \\
\hline
\end{tabular}

Additionally, there are some anomalies: WORRYPEACE is significant for all models but it has the wrong sign. And for the pooled data every variable is significant. As this is valid not only for the variables chosen for Model 8 but also for the variables that were investigated but skipped, this leads to the assumption that simple linear regression provides no appropriate

\footnotetext{
${ }^{1} 1992$ instead of 1991 was chosen to avoid outliers due to the German unification.
} 
model to fit the data. To clarify this issue, the regression estimates were supplement by some fixed effects models. And to get an answer for the question what has happened from 2008 to 2011, the model for 2008 presented in Oltmanns, Braakmann and Schmidt (2012) was applied for the single years. But the results for both investigations were ambiguous and are not reported here.

\subsection{Evaluation of results}

The models presented in the previous chapter have identified several variables that predominantly determine the satisfaction with life. These variables show a significant influence on the satisfaction with life. The results hold for regression grouped by the status of employment, in the course of time and for the pooled data from 1992 to 2011.

The role of other variables is far away from a clear interpretation. For instance, the variable WORRYECON (worry about the economic development) is only significant for 2001 and for the pooled data. On the other hand, it has had a significant influence on satisfaction with life in 2008, as reported by Oltmanns, Braakmann and Schmidt (2012). The variable WORRYENV is significant in some cases and in other cases not. But in every estimate it has the wrong sign.

\section{Conclusion}

In this paper it was investigated which factors determine the satisfaction with life. A set of selected indicators was used to construct single equation regression models. The estimated models identified soft factors like satisfaction with health or satisfaction with work as well as the (absence of) worries about the own economic situation that predominantly determine the satisfaction with life.

Even if the results were unambiguous according to the selected variables it seems necessary to broaden the investigation. The longitudinal results show significant differences in the course of time, maybe due to the business cycle. Therefore, it would be useful to supplement the regression models by appropriate panel data models and to include variables reflecting the general economic situation. Also, the analysis should be broaden by including additional variables from the SOEP like "Satisfaction with friends and acquaintances" or "spare time activities" into the models.

The data from the SOEP refer to Germany only. The results achieved are not valid for other countries. Therefore, it would be useful to repeat the estimates with other data. Cause of its international coverage, the data from EU-SILC seem to be very useful here. 


\section{References}

Blanchflower, D. G. (2009): International Evidence on Well-Being. In: A. B. Krueger (Eds.), Measuring the Subjective Well-Being of Nations. Chicago, London: University of Chicago Press, p. $155-226$.

Braakmann, Albert (2010): "Zur Wachstums- und Wohlfahrtsmessung. Die Vorschläge der Stiglitz-Sen-Fitoussi-Kommission und der Initiative "BIP und mehr", Wirtschaft und Statistik, 7/2010, p. $609-614$.

Commission of the European Communities (2009): Communication from the Commission to the Council and the European Parliament. GDP and beyond. Measuring progress in a changing world. Brussels, 20.8.2009 COM(2009) 433 final.

(http://eur-lex.europa.eu/LexUriServ/LexUriServ.do?uri=COM:2009:0433:FIN:en:PDF)

Commission on the Measurement of Economic Performance and Social Progress (2008): Survey of existing approaches to measuring socio-economic progress.

(http://www.stiglitz-sen-fitoussi.fr).

Commission on the Measurement of Economic Performance and Social Progress (2009): Report of the Commission on the Measurment of Economic Performance and Social Progress. (http://www.stiglitz-sen-fitoussi.fr).

DIW Berlin: SOEP Innovation Survey (http://www.diw.de/en/diw 01.c.390440.en/soep is.html)

Eurostat (2010): Income and living conditions in Europe. Edited by Anthony B. Atkinson and Eric Marlier. Luxembourg: Publications Office of the European Union

Ferrer-i-Carbonell, Ada and Paul Frijters (2004): "How important is Methodology for the estimates of the determinants of Happiness?", The Economic Journal, 114 (July), p. $641-$ 659.

Frick, Joachim R. and Kristina Krell (2011): "Einkommensmessungen in Haushaltspanelstudien für Deutschland: Ein Vergleich von EU-SILC und SOEP (Measuring income in household panel surveys for Germany: a comparison of EU-SILC and SOEP", AstA-Wirtschaftsund Sozialstatistisches Archiv 5, p. 221 - 248.

Frick, Joachim and Ingo Sieber (2012): SOEP Samples Overview - 2011 / Wave 28 (http://panel.gsoep.de/soepinfo2011/info/soep samples size.pdf)

Fromm, Erich (1959): The sane society. Second edition, London: Routledge \& Kegan Paul Ltd.

Fromm, Erich (1994): Credo. In: Reiner Funk (Ed.): E. Fromm, On Being Human, New York, Continuum, p. 99-105. 
García Díez, Susana (2012): Well-being Indicators. Questions of Quality. The Perspective of Official Statistics. Paper to be presented at the European Conference on Quality in Official Statistics, Q2012, 29 May - 1 June 2012, Athens, Greece

(http://www.q2012.gr/articlefiles/sessions/26.3 GarciaDiez Well\%20being\%20indicators \%20paper.pdf)

German Council of Economic Experts and Conseil d'Analyse Economique (2010): Monitoring Economic Performance, Quality of Life and Sustainability. Joint Report as requested by the Franco-German Ministerial Council, December 2010

(http://www.sachverstaendigenrat-

wirtschaft.de/fileadmin/dateiablage/Expertisen/2010/ex10 en.pdf).

Goebel, Jan (2014a): SOEP Documentation Codebook: Generated Variables - Personal level (http://panel.gsoep.de/ urahmann/codebook pgen.pdf)

Goebel, Jan (2014b): SOEP Documentation Codebook: Person level questionnaires (http://panel.gsoep.de/ urahmann/codebook p.pdf)

Greene, William H. (2012): Econometric Analysis. $7^{\text {th }}$ edition, Boston [et. al.]: Pearson, 2012.

Haisken-DeNew, J. P. and J. Frick (2005): Desktop Companion to the German Socio-Economic Panel Study (GSOEP). German Institute for Economic Research, Berlin.

Hajek, André (2011): Lebenszufriedenheit und Einkommensreichtum: Eine empirische Analyse mit dem SOEP (SOEP Papers ; 362).

Kahneman, Daniel, Ed Diener and Norbert Schwarz [eds.] (1999), Well-Being: The Foundation of Hedonic Psychology. New York: Russell Sage Foundation.

Kassenboehmer, Sonja C. and Christoph M. Schmidt (2011): Beyond GDP and back: What is the Value-added by Additional Components of Welfare Measurement? (Ruhr Economic Papers \#239) (http://www.rwi-essen.de/publikationen/ruhr-economic-papers/354/).

Kroh, Martin (2014): Documentation of Sample Sizes and Panel Attrition in the German Socio Economic Panel (SOEP) (1984 until 2012), DIW Berlin (SOEP Survey Papers 177 ; Series D. Variables Description and Coding)

(http://panel.gsoep.de/soep-docs/surveypapers/diw ssp0177.pdf)

Nordhaus, W./Tobin, J. (1972): „Is growth obsolete?“ in: National Bureau of Economic Research, Economic Research: Retrospect and Prospect, Vol 5: Economic Growth.

OECD (2013): How's Life? 2013. Measuring Well-being. OECD Publishing.

(http://www.keepeek.com/Digital-Asset-Management/oecd/economics/how-s-life2013 9789264201392-en)

Oltmanns, E., A. Braakmann und J. Schmidt (2012): “Measuring the quality of life. Empirical evidence for Germany". Paper to be presented at the $32^{\text {nd }}$ Conference of the International Association for Research in Income and Wealth (IARIW) in Boston - Cambridge (USA), 5 - 11. August 2012. (http://www.iariw.org/papers/2012/OltmannsPaper.pdf)

Study Commission on Growth, Well-being and Quality of Life (2013): Paths to Sustainable Economic Activity and Social Progress in the Social Market Economy. [English] Summary of the conclusions and main recommendations of the "Enquete-Kommission „Wachstum, 
Wohlstand, Lebensqualität - Wege zu nachhaltigem Wirtschaften und gesellschaftlichem Fortschritt in der Sozialen Marktwirtschaft. Deutscher Bundestag. Drucksache 17/13300.“ May 2013

(http://webarchiv.bundestag.de/archive/2013/1212/bundestag/gremien/enquete/wachst um/Schlussbericht/Endversion EN.pdf)

Wagner, Gert G., Jan Göbel, Peter Krause, Rainer Pischner and Ingo Sieber (2008): "Das Sozio-oekonomische Panel (SOEP): Multidisziplinäres Haushaltspanel und Kohortenstudie für Deutschland - Eine Einführung (für neue Datennutzer) mit einem Ausblick (für erfahrene Anwender)", ASTA - Wirtschafts- und Sozialstatistisches Archiv 2, p. 301 - 328.

Wagner, Gert G., Joachim R. Frick and Jürgen Schupp (2007): "The German Socio-Economic Panel Study (SOEP) - Scope, Evolution and Enhancements", Schmollers Jahrbuch 127, No. 1 , p. $139-169$.

Wikipedia. The Free Encyclopedia: "Socio-Economic Panel" (http://en.wikipedia.org/wiki/Socio-Economic Panel)

All URLs accessed on $29^{\text {th }}$ July 2014. 